\title{
An Empirical Study on Microbial Load and Acidity in Raw Milk Produced in Malayer and Nahavand Cities, Iran 2012
}

\author{
Mohammad Rezaei', Ali Asghar Behzadi'2, Ali Akbar Malekirad³, Ahmad Fattahi, \\ Mohamad Hadi Farahzadi5, Mohammad Sarmadi6, Hasan Mohammadi Aghamirlou', \\ Reza Ali Fallahzadeh ${ }^{*}$ \\ ${ }^{1}$ Department of Food Safety and Hygiene, School of Public Health, Tehran University of Medical Sciences, \\ Tehran, Iran \\ ${ }^{2}$ Department of Food Safety and Hygiene, School of Health, Yazd University of Medical Sciences, Yazd, Iran \\ ${ }^{3}$ Department of Biology, Payame Noor University, Tehran, Iran \\ ${ }^{4}$ Department of Occupational Health Engineering, School of Health, Shahid Sadoughi University of Medical \\ Sciences, Yazd, Iran \\ ${ }^{5}$ Department of Neuroscience, School of Advanced Technologies in Medicine, Tehran University of Medical \\ Sciences, Tehran, Iran \\ ${ }^{6}$ Department of Environmental Health and Engineering, School of Public Health, Tehran University of Medical \\ Sciences, Tehran, Iran \\ ${ }^{7}$ Department of Environmental Health Engineering, School of Health, Shahid Sadoughi University of Medical \\ Sciences, Yazd, Iran \\ Email: ${ }^{*}$ fallahzadeh4@yahoo.com
}

Received 5 July 2014; revised 19 August 2014; accepted 3 September 2014

Copyright (C) 2014 by authors and Scientific Research Publishing Inc.

This work is licensed under the Creative Commons Attribution International License (CC BY).

http://creativecommons.org/licenses/by/4.0/

(c) (i) Open Access

\section{Abstract}

Milk is very susceptible for growth and development of many microorganisms because it is rich in nutrients and has suitable condition. Thus, it is very vital to respect sanitary conditions at all stages of production and transport of raw milk. The objective of the present investigation was to determine the total bacterial, and acidity in raw milk from milk collection centers in Malayer and Nahavand cities. 52 milk samples were collected from 13 centers in summer 2012 and were analyzed according to standard methods. None of the raw milk samples under investigation, had superior or grade 1 quality. Only $7.7 \%$ of the samples were classified as raw milk with grade 2 quality and $92.3 \%$ were non-standard. The mean of microbial total count in base was $3.8 \times 10^{7} \mathrm{CFU} / \mathrm{ml}$ and average acidity in the samples was 0.163 . The city of Tochqhaz and Aliabad-e-Damagh has the

\footnotetext{
${ }^{*}$ Corresponding author.
}

How to cite this paper: Rezaei, M., Behzadi, A.A., Malekirad, A.A., Fattahi, A., Farahzadi, M.H., Sarmadi, M., Aghamirlou, H.M. and Fallahzadeh, R.A. (2014) An Empirical Study on Microbial Load and Acidity in Raw Milk Produced in Malayer and Nahavand Cities, Iran 2012. Health, 6, 2184-2189. http://dx.doi.org/10.4236/health.2014.616253 
lowest and the highest microbial total count. In general the result of this study showed unsatisfactory conditions of milk in the milk collection centers of the Malayer and Nahavand cities.

\title{
Keywords
}

\author{
Food Safety, Milk Collection Centers, Acidity, Microbial Total Counts
}

\section{Introduction}

Milk as a valuable food source is rich in calcium, phosphorus, required vitamins and proteins. According to FAO and WHO studies, 50 percent of total daily protein requirements should be coming from animal protein [1].

Milk quality is one of the important indicators along the extent of the consumed quantity. The initial quality of raw milk is affected by factors such as animal nutrition, animal health, chemical composition and microbial activity. So the quality of raw milk will depend on many factors such as duration and conditions of milk production site to delivery to the plant [2]. Determine the total microbial load in milk is a common method and most significant criterion in evaluating the quality of raw milk [3].

The total number of bacteria is important in milk for appropriate assessment for human consumption; its importance is due to the presence of bacteria that can cause illness in the consumer. The pathogenic bacteria such as coliform are important. The presence of fecal coliform, such as Escherichia coli, indicates fecal contamination with animal feces. Because these bacteria are common flora of warm-blooded animals, therefore, its presence in milk is harmful to consumers [4].

Milk is delivered to factory for processing from production units or deliver to factory after collection in collection centers in the mobile or stationary stations.

In this cycle increasing microbial load is inevitable but its indiscriminate increase is controllable [5].

Hamadan has important role in milk production in Iran by producing 435.7 thousand tons of milk (more than $4 \%$ of the total milk produced in the country) [5]. Major parts of production come from traditional unit that located in village and their produced milk transferred to the factory through milk collection centers, so well be understood the importance of milk bacteriological quality in collection stations in order to identify the most important contaminate foci of raw milk from milking stage to delivery to factory. This study was performed to achieve this goal and assess the microbial contamination (microbial load and total acidity).

\section{Materials and Methods}

Since the traditional dairy farmers deliver their milk to the collection centers, Milk samples collected from 13 stations of Malayer and Nahavand city. 4 samples from each station were collected in summer 2012.

All samples (52 samples) have been transferred to the microbiology laboratory in cold and sterile conditions.

In the laboratory, Serial dilutions of raw milk samples were produced and cultured for total microbial counts by surface culture method on Plate Count Agar (With three replications). After 3 days incubation at $30^{\circ} \mathrm{C}$ microorganisms were counted according to standard methods [6]. Acidity test calculated according to the Dornic degree by Titration with sodium hydroxide.

\section{Findings}

Table 1 shows the average of total microbial load and acidity in each collection center. The city of Tochqhaz and Aliabad-e-Damagh has the lowest and the highest microbial total count in comparison with other centers $\left(2.56 \times 10^{6}\right.$ and $\left.7.3 \times 10^{7}\right)$.

While the average acidity of the collected samples in Kasb (0.153) and Aliabad-e-Damagh (0.18) had minimum and maximum acidity according to Dornic degree. 92.3\% of the samples have a higher microbial load than standard dairy factories for processing (Table 2). Figure 1 and Figure 2 show the logarithm of microorganisms and acidity of milk collection stations. 
Table 1. Microbial and acidity average load per station.

\begin{tabular}{|c|c|c|c|}
\hline Station & Number of Samples & Total Microbial Load [Mean \pm SD CFU/ml] & Acidity \\
\hline Jokar & 4 & $1.64 \times 10^{7} \pm 3.6 \times 10^{5}$ & 0.166 \\
\hline Kasb & 4 & $3.8 \times 10^{6} \pm 9 \times 10^{4}$ & 0.153 \\
\hline Dehno & 4 & $2.73 \times 10^{6} \pm 4.5 \times 10^{4}$ & 0.156 \\
\hline Malayer & 4 & $5 \times 10^{6} \pm 6.2 \times 10^{4}$ & 0.156 \\
\hline Aliabad-e-Damagh & 4 & $3.7 \times 10^{7} \pm 1.2 \times 10^{6}$ & 0.180 \\
\hline Hossinabad-e-Shamlu & 4 & $2.6 \times 10^{6} \pm 9.3 \times 10^{4}$ & 0.160 \\
\hline Mehrabad & 4 & $1.25 \times 10^{7} \pm 4 \times 10^{5}$ & 0.163 \\
\hline Tochqhaz & 4 & $2.56 \times 10^{6} \pm 8.1 \times 10^{4}$ & 0.156 \\
\hline Shiravaran & 4 & $2.27 \times 10^{7} \pm 4.6 \times 10^{4}$ & 0.170 \\
\hline Doraneh & 4 & $5.2 \times 10^{6} \pm 1.8 \times 10^{5}$ & 0.163 \\
\hline Nahavand & 4 & $1.14 \times 10^{7} \pm 3.2 \times 10^{5}$ & 0.170 \\
\hline Kahriz & 4 & $2.8 \times 10^{7} \pm 1.8 \times 10^{6}$ & 0.170 \\
\hline Dehfoul & 4 & $1.2 \times 10^{7} \pm 4.6 \times 10^{5}$ & 0.163 \\
\hline Mean & & $1.2 \times 10^{7}$ & 0.164 \\
\hline Range & & $2.56 \times 10^{6}-3.7 \times 10^{7}$ & $0.153-0.180$ \\
\hline
\end{tabular}

Table 2. Distribution of stations in terms of raw milk quality according to Iranian national standard.

\begin{tabular}{cccc}
\hline Total Counts Standard [CFU/ml] & Number of Stations & Ranking of Milk According to Iranian Standard & Percent \\
\hline$<30,000$ & 0 & Excellent & 0 \\
$30,000-100,000$ & 0 & First Degree & 0 \\
$100,000-500,000$ & 1 & Second Degree & 7.7 \\
$500,000-1,000,000$ & 0 & Third Degree & 0 \\
$>1,000,000$ & 12 & Non-Standard & 92.3 \\
\hline
\end{tabular}

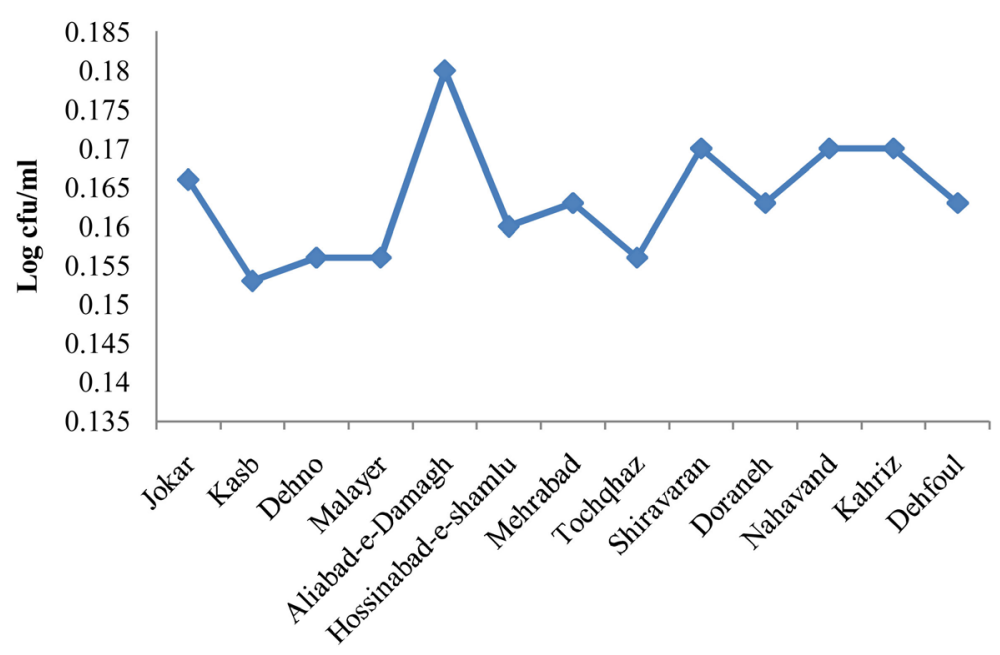

Milk Collection Centers

Figure 1. Logarithm of raw milk microbial load in collection centers.

\section{Discussion}

Pathogenic bacteria in milk have been a major problem for public health concern. Evaluation of raw milk quality in milk collection centers as one of the main focal is important in increasing the quality of raw milk delivered to factory. Because in the absence of hygiene, Milk contamination probability is high. In a study conducted in the 


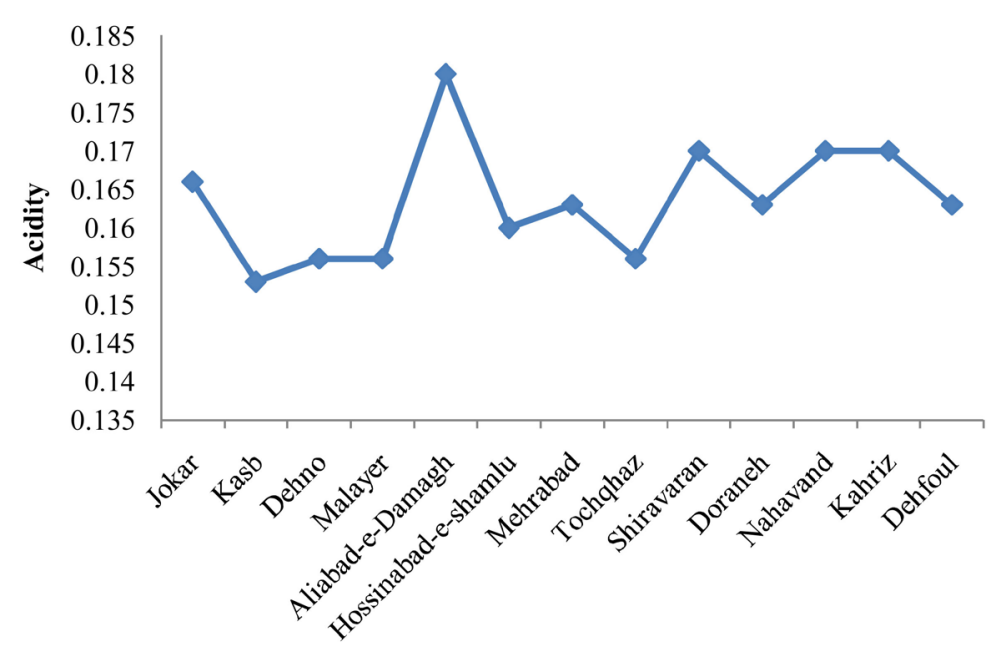

Milk Collection Centers

Figure 2. Milk acidity rate according to the Dornic degree in collection centers.

Lorestan province, the logarithm of the average microbial load of milk was 6.43 in collection centers with different capacities during 2003, and the average of Escherichia coli was 13.3 over the year [7]. Average logarithm of microbial load of raw milk in traditional dairy collection tank and milk tanker in podium at the factory in the city of Kashmar were reported 6.9 and 6.8 respectively [8].

Kamalzadeh (2010) in a study was conducted on 54 samples of raw milk in milk collection centers in the Khozestan province, none were reported excellence in terms of national standards, and about $88.3 \%$ of samples were non-standard [3] which is consistent with results from the present study. Logarithmic average microbial load was 7.1 in milk collection centers, has difference with these results and indicate a higher quality of raw milk in milk collection centers in the Hamadan province. Logarithmic average microbial load of milk tank was 6.9 in milk collection centers in the Fars province, and the results was approximately equal to result of the present study [7]. In the study that conducted in Yazd, average microbial load was 15.96 that in compared with the present results is the very high rate. In the study that conducted by Ibrahim Mohammed (2011) the average of microbial load of milk reported 8.5 in milk collection centers in the city of Mahabad [9]. Yarahmadi reported the average of microbial load of milk 6.8 in a study that conducted on 2560 record of raw milk in the Lorestan province during 1399 to 2001 [1]. In a study in India the logarithmic average microbial loads of milk samples from 124 centers were reported between 2.2 to 2.6 [10], which appear highly desirable when compares with the results of this study. Holm et al. (2004) reported that the logarithmic average microbial load of raw milk in 75 milk collection was 2.4 [11]. In the study that conducted by Van Schaik et al. (2004) the microbial load of raw milk in 42 milk collection centers in Chile's was 3.8 [12]. This rate reported 2.1 for Ethiopia in the study that conducted by Godefay et al. (2000) [13]. The Average logarithmic microbial load of raw milk from Markazi Province was $6.8 \mathrm{CFU} / \mathrm{ml}$ which was consistent with our results [14]. The presence of various contaminants in food by authors has also been investigated in other studies in Iran [14]-[19]. Ombui et al. (1994) reported that the rate of microbial load of raw milk in collection centers in Kenya was 2.7 and about $50 \%$ of the samples had coliform contamination [20]. Differences between the reports and the results of this study could be related to milk collection centers or the product process steps until it is delivered to the center. Due to the high sensitivity of milk, several factors can affect on milk quality; factors such as sanitation and washing the udder before milking, mastitis control, animal health status, hygiene of milking utensils and tankers, time spent between milking milk to transfer it to the center, personal hygiene, maintenance milk in proper temperature, etc. There are many studies in this field represents the significant impact of these factors on milk quality [3] [5] [12] [13] [21] and [22]. Besides these factors, year and season of sampling can also affect on differences between the results [1] [2] [5] and [8].

An outbreak of zoonotic pathogen, Streptococcus zooepidermicus was reported in Australia in 1992 involving three cases who had reportedly consumed unpasteurized milk from a house cow [23]. Disease outbreaks associated with consumption of raw milk are considerably higher than outbreaks associated with the consumption of 
pasteurized milk.

The safety of raw cow milk is influenced by a combination of management and control measures along the entire dairy supply chain. Control of animal health, use of correct milking practices, and control over milking parlor hygiene are important factors in reducing the microbial load in raw milk.

\section{Conclusion}

The results indicate the poor quality of raw milk produced in Malayer and Nahavand cities. Hence, raising the level of food safety for consumers is an essential infrastructural measure to improve conditions, dairy farmers and their family member's education, training operators of milk collection centers and etc.

\section{References}

[1] Yarahmadi, B., Eslami, M., Mahdavi, H. and Moayedi nejad, A. (2006) The Survey of Bacteriological Quality Raw Milk and Seasonal Affecting factors in Lorestan province. Animal Sciences Journal, 70, 28-33.

[2] Yarahmadi, B., Mahdavi, H. and Moayedi nejad, A. (2008) Evaluation of Total Microbial Contamination, Coliforms and Escherichia coli of Raw Milk from Milking until Delivered to the Factory in Lorestan Province. Lorestan Medical University Journal, 10, 67-87.

[3] Kamal zade, L., Kamal zade, A. and Heydar nejad, A. (2010) Total Bacterial, Coliforms and the Staphylococcus Aureus Bacteria Count of Raw Milk (from Farms to the Processing Factory), and Pasteurized Milk in Khozestan Province. The Fourth Congress on Animal Science, Karaj, 15-16 September 2010, 282-288.

[4] Aleksieva, V. and Krushev, B. (1981) Quality of Raw Cow’s Milk. Veterinarno-Meditsinski Nauki, 18, 65-71.

[5] Imami meybodi, M.A., Mahdavi adali, H.R., Shokohmand, M., Karimi, A. and Mophidi, M.R. (2010) The Survey of Microbial Load and Raw Milk Additives in Yazd Province. The Fourth Congress on Animal Science, Karaj, 15-16 September 2010, 204-209.

[6] ISIRI (2008) Microbiology of Milk and Its Products. Institute of Standards and Industrial Research of Iran, 2406.

[7] Hashemi, M. and Shekarforosh, M.S.H. (2007) The Survey of Microbial and Chemical Changes of Raw Milk from Different Stages of Production until Dairy Factory in the Fars Province. Iranian Journal of Veterinary Medicine, 3, 81-87.

[8] Khosravi, M. and Ghaznavi, A. (2008) The Survey of Microbial Load and PH Traditional Animal Husbandry Milk Collected from Kashmar City in Different Seasons. Journal of Modern Agricultural, 4, 34-37.

[9] Ebrahimi, M.K. (2012) Evaluate the Microbial Quality of Raw Milk in Dairy Cattle Units and Milk Collection Centers in Mahabad City. The First National Congress of Dairy and Related Industries, Qom, 17 February 2012, 79-84.

[10] Desai, P. and Natarajan, A. (1981) Bacteriological Quality of Raw Milk Collected from Societies for Transportation to Chilling Centres. Cheiron, 10, 149-150.

[11] Holm, C., Mathiasen, T. and Jespersen, L. (2004) A Flow Cytometric Technique for Quantification and Differentiation of Bacteria in Bulk Tank Milk. Journal of Applied Microbiology, 97, 935-941. http://dx.doi.org/10.1111/j.1365-2672.2004.02346.x

[12] Van Schaik, G., Green, L.E., Guzman, D., Esparza, H. and Tadich, N. (2004) Risk Factors for Bulk Milk Somatic Cell Counts and Total Bacterial Counts in Smallholder Dairy Farms in the 10th Region of Chile. Preventive Veterinary Medicine, 67, 1-17. http://dx.doi.org/10.1016/j.prevetmed.2004.10.002

[13] Godefay, B. and Molla, B. (2000) Bacteriological Quality of Raw Cow’s Milk from Four Dairy Farms and a Milk Collection Centre in and around Addis Ababa. Berliner und Münchener tierärztliche Wochenschrift, 113, 276-278.

[14] Rezaei, M., Karimi, F., Yahyaei, M., Javdani, H., Shahabi, A. and Farahi, A. (2013) A Survey of Microbial Total Count and Prevalence of Escherichia coli in Raw Milk in Markazi Province, Iran. Research Opinions in Animal and Veterinary Sciences, 3, 474-477.

[15] Fani, A., Rezaei, M., Moini, A., Fani, P., Mirzajani, P., Malekirad, A.A., et al. (2013) Aflatoxin Occurrence in Nuts Consumed in Arak, Iran. International Journal of Food Safety, 4, 91-97.

[16] Rezaei, M., Shariatifar, N., Jahed Khaniki, G. and Javadzadeh, M. (2013) Nitrite in Hamburgers in Arak, Iran. Food Additives \& Contaminants: Part B, 6, 285-288. http://dx.doi.org/10.1080/19393210.2013.822933

[17] Rezaei, M., Dastjerdi, H.A., Jafari, H., Farahi, A., Shahabi, A., Javdani, H., et al. (2014) Assessment of Dairy Products Consumed on the Arak Market as Determined by Heavy Metal Residues. Health, 6, 323-327. http://dx.doi.org/10.4236/health.2014.65047

[18] Rezaei, M., Karimi, F., Parviz, M., Behzadi, A.A., Javadzadeh, M., Mohammadpourfard, I., Fallahzadeh. R.A., et al. (2014) An Empirical Study on Aflatoxin Occurrence in Nuts Consumed in Tehran, Iran 2013. Health, 6, 649-653. 
http://dx.doi.org/10.4236/health.2014.68084

[19] Rezaei, M., Mohammadpourfard, I., Malekirad, A.A., Ghasemikhah, R. and Sayadi, M. (2014) Aflatoxin Contamination of Feed Materials in Qom Province, Iran. Iranian Journal of Toxicology, 8, 1025-1027.

[20] Ombui, J.N., Kaburia, H.F., Macharia, J.K. and Nduhiu, G. (1994) Coliform Counts and Escherichia coli in Raw Commercial Milk from Dairy Farmers in Kiambu District, Kenya. East African Medical Journal, 71, 635-639.

[21] Arab ameri, M., Zolfaghari, M., Nazarian, A., Norian, A. and Jalali, A. (2009) Study of Bacterial Contamination of Raw and Pasteurized Milk in the Shahrod City in 2008. Journal of Applied Microbiology, 97, 935-943.

[22] Lopes, A.C. and Stamford, T.L. (1997) Critical Control Points in the Pasteurized Milk Processing Fluxogram. Archivos Latinoamericanos de Nutrición, 47, 367-371.

[23] Francis, A.J., Nimmo, G.R., Efstratiou, A., Galanis, V. and Nuttall, N. (1993) Investigation of Milk-Borne Streptococcus zooepidemicus Infection Associated with Glomerulonephritis in Australia. Journal of Infection, 27, 317-323. http://dx.doi.org/10.1016/0163-4453(93)92358-4 
Scientific Research Publishing (SCIRP) is one of the largest Open Access journal publishers. It is currently publishing more than 200 open access, online, peer-reviewed journals covering a wide range of academic disciplines. SCIRP serves the worldwide academic communities and contributes to the progress and application of science with its publication.

Other selected journals from SCIRP are listed as below. Submit your manuscript to us via either submit@scirp.org or Online Submission Portal.
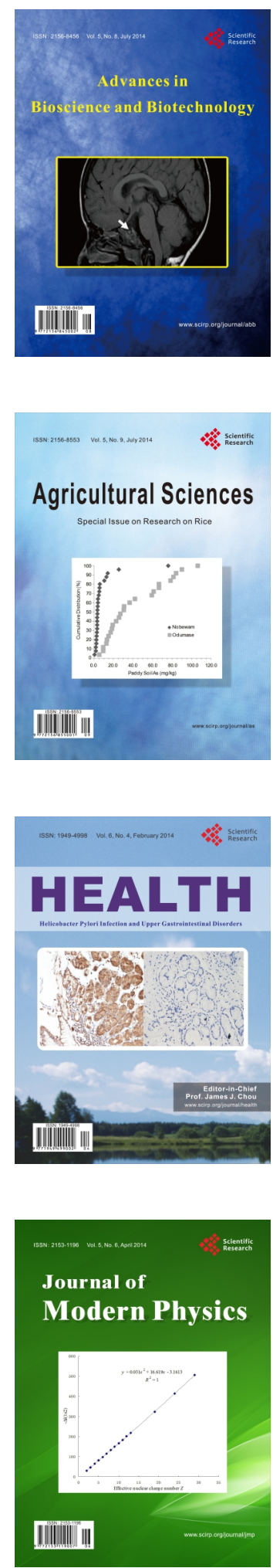
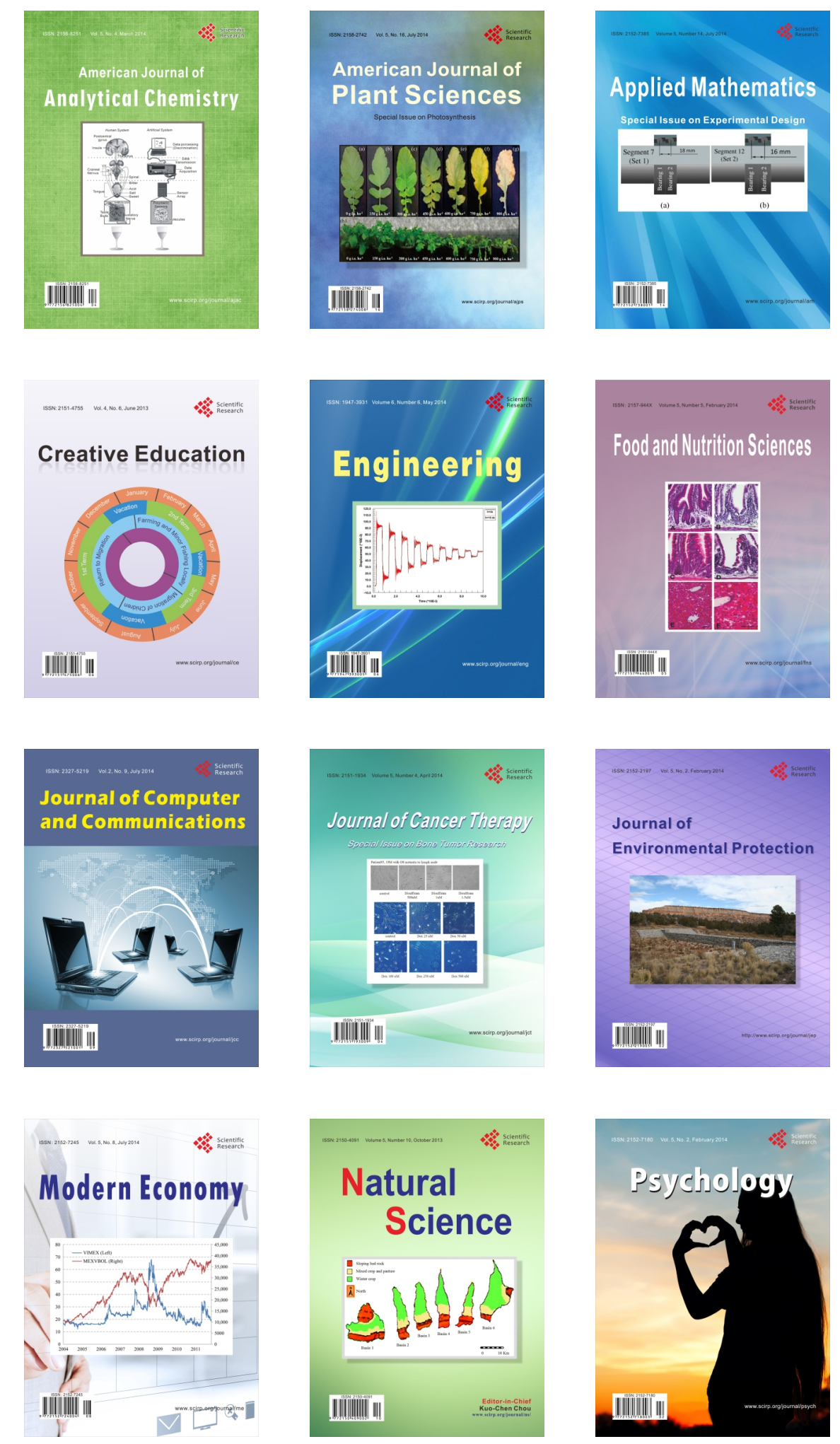